\title{
Biogeographical diversity among marine bacterioplankton
}

\author{
Åke Hagström ${ }^{1, *}$, Jarone Pinhassi $^{2}$, Ulla Li Zweifel ${ }^{1}$ \\ ${ }^{1}$ Marine Science, Kalmar University, Box 905, 39129 Kalmar, Sweden \\ ${ }^{2}$ Department of Microbiology, Umeá University, 90187 Umeå, Sweden
}

\begin{abstract}
The phylogenetic diversity of bacteria isolated on solid media from the Baltic Sea, Mediterranean Sea, Southern California Bight, Skagerrak, Weddell Sea (ice) and Andaman Sea was investigated by means of $16 \mathrm{~S}$ rRNA gene sequence analysis. Of the 128 sequenced isolates, $52 \%$ showed similarity on the species level to previously reported bacteria, while as many as $18 \%$ showed a sequence similarity below $93 \%$, which in the closest case would represent difference at the genus level. A majority of the isolated $\gamma$-Proteobacteria could be assigned to known species, while half of the $\alpha$-Proteobacteria were only identified to the genus level. Bacteria affiliated with the FlexibacterCytophaga-Bacteroides phylum showed the lowest levels of similarity to previously sequenced bacteria, mainly representing novel genera. Closely related isolates most of ten originated from the same geographic area. Nevertheless, our data also demonstrated that most genera have closely related representatives widely distributed between different sea areas. Isolates related to environmental clones, with a sequence similarity above the tentative genus level, were found in 51 cases, of which 17 were more similar to clones than to cultured bacteria. From this result we concluded that a large proportion of the great species richness of marine bacteria, found by culture-independent techniques, is likely to be verified through information from live and functional bacteria.
\end{abstract}

KEY WORDS: Diversity $\cdot$ Bacterioplankton - 16S rRNA

\section{INTRODUCTION}

The paramount importance of microbial life for the cycling of matter in the oceans makes finding the identity and phylogenetic diversity of the indigenous bacteria an obvious research goal. Presently, the phylogenetic tree of marine bacterioplankton is rapidly growing. This is largely a result of extensive cloning of bacterial 16S rRNA genes from the environment, which has revealed a large number of novel taxonomic groups (Giovannoni et al. 1990, Fuhrman et al. 1992, 1993, DeLong et al. 1993, Mullins et al. 1995, Acinas et al. 1999). However, since a large majority of these novel taxa are not yet represented by bacteria in culture, the phenotypic expression of these bacteria remains unknown. Microbiologists came to the conclusion that a majority of the bacteria in the sea were

\footnotetext{
•E-mail: ake.hagstrom@ng.hik.se
}

unculturable since only a small proportion of the bacteria counted by epifluorescence microscopy were able to form colonies on solid media (Jannasch \& Jones 1959, Kogure et al. 1979). The remaining bacteria were believed to be unable to grow in culture using thenpresent techniques. This bias against cultured bacteria has been an essential element in the decision to study cloned bacterial DNA instead of isolates of marine bacteria (Giovannoni et al. 1990, Fuhrman et al. 1992, Amann et al. 1995, Pace 1996, Fuhrman \& Campbell 1998). However, another valid explanation for the discrepancy between total counts of bacteria and colonyforming units might be low plating efficiency due to virus infection or nutrient stress (Rehnstam et al. 1993, Nyström 1998). In line with this reasoning several recent studies using various hybridization protocols have demonstrated that bacteria that are able to grow on solid media occupy a significantly higher fraction of the bacterial community than the number of colonies 
on the plates would suggest (Rehnstam et al. 1993, Fuhrman et al. 1994, Moran et al. 1995, Faude \& Höfle 1997. González \& Moran 1997, Pinhassi et al. 1997, 1999, Tuomi et al. 1997. Weinbauer \& Höfle 1998). Thus, significant species information from live and functional bacteria is currently being added to the phylogeny of marine bacteria.

Concurrent with the accumulation of data on the identity of marine bacteria, several authors have addressed questions regarding the biogeographic distribution of marine bacteria. Lee \& Fuhrman (1991) made gross comparisons of the bacterial species composition using a whole community DNA hybridization technique, showing that 3 samples from widely separated sea areas (Pacific Ocean, Long Island Sound, Caribbean Seaj had less than $16 \%$ similarity. However, soon thereafter DeLong (1992) found similar Archaea in both Pacific and Atlantic US coastal waters, and Fuhrman et al. (1993) also reported 2 pairs of cloned sequences identical between the Southern California Bight and the Sargasso Sea (DeLong 1992, Fuhrman et al. 1993). Furthermore, Mullins et al. (1995) found several near-identical bacterial sequences from different oceans (Mullins et al. 1995). Based on this information these authors emphasized the presence of a few key microbial groups with widespread occurrence.

Throughout the brief period of marine bacterial phylogeny a major concern has been how to place the new clones and isolates into appropriate taxa. The current species concept in systematic bacteriology is based on the level of crosshybridization between genomic DNA of different strains of bacteria: if crosshybridization is $>70 \%$, the bacteria belong to the same species (Wayne et al. 1987). This species criterion was further defined by Stackebrandt \& Goebel (1994), who demonstrated that bacteria with crosshybridization levels $<70 \%$ never have a $16 \mathrm{~S}$ rDNA sequence similarity $>97 \%$, and similar results have been presented by others (Devereux et al. 1990, Amann et al. 1992). In accordance with these data the intraspecies variability in the 16S rDNA for a number of bacteria have been reported to be low $(<2 \%)$, although not necessarily zero (Wiik et al. 1995, Field et al. 1997, Yoon et al. 1998). Using these criteria as a basic assumption we previously demonstrated seasonal and short-term succession of different marine bacterial species (Pinhassi et al. 1997, 1999).

In this paper we present information on bacterial isolates collected from different sea areas, some of which have been shown to be important indigenous members of the marine bacterioplankton based on their demonstrated occurrence in the community DNA. In a simple manner the obtained species collection offered a possibility to present a first sketch of the phylogenetic affiliation and biogeographic distribution of cultured marine bacteria.

\section{MATERIALS AND METHODS}

Sampling and isolation of bacteria. Bacterial isolates were obtained by spreading samples of seawater onto Zobell agar plates. An effort was made to get representatives of all present colony morphologies in each sample. Samples were collected off the Thailand coast in the Andaman Sea $\left(08^{\circ} 00^{\prime} \mathrm{N}, 98^{\circ} 00^{\prime} \mathrm{E}\right)$, from the Weddell Sea in Antarctica $\left(65^{\circ} 00^{\prime} \mathrm{S}, 47^{\circ} 00^{\prime} \mathrm{E}\right)$, in the Skagerrak $\left(58^{\circ} 56^{\prime} \mathrm{N}, 11^{\circ} 45^{\prime} \mathrm{E}\right)$, at point $\mathrm{B}$ in the bay of Villefranche-sur-Mer in the Mediterranean Sea $\left(43^{\circ} 41^{\prime} N, 7^{\circ} 19^{\prime} \mathrm{E}\right)$, off Scripps Pier in the Southern California Bight $\left(32^{\circ} 53^{\prime} \mathrm{N}, 117^{\circ} 15^{\prime} \mathrm{W}\right)$, and at Stn NB1 in the northern Baltic Sea $\left(63^{\circ} 30^{\prime} N, 19^{\circ} 48^{\prime}\right.$ E). Pure cultures of the isolates were stored in glycerol $20 \%$ final concentration) at $70^{\circ} \mathrm{C}$ for subsequent phylogenetic characterization.

PCR-amplification, purification of PCR product and sequencing. 16S rRNA gene sequences of bacterial isolates from different sea areas were amplified by means of PCR (polymerase chain reaction) using Taq polymerase (Boehringer-Mannheim) from DNA preparations of cultured isolates. Bacterial 16S rDNA primers, 27f:biotinylated (AGAGTTTGATCATGGCTCAG) and 1492r (TACGGYTACCTTGTTACGACTT), were used for amplification (Giovannoni 1991). The reaction volumes were $50 \mu \mathrm{l}$, containing $1 \mu \mathrm{g}$ template (genomic DNA), $10 \mathrm{mM}$ total dNTP, standard $10 \times$ Taq buffer, a total of $15 \mathrm{ng}$ of each primer, and $1 \mathrm{U}$ of Taq polymerase. The PCR amplification conditions were as follows: 1 round of denaturation at $95^{\circ} \mathrm{C}(2 \mathrm{~min})$, annealing at $50^{\circ} \mathrm{C}(30 \mathrm{~s})$ and elongation at $72^{\circ} \mathrm{C}(45 \mathrm{~s})$ and then 29 cycles of $95^{\circ} \mathrm{C}(30 \mathrm{~s}), 50^{\circ} \mathrm{C}(30 \mathrm{~s})$ and $72^{\circ} \mathrm{C}(45 \mathrm{~s})$ using a DNA thermal cycler 480 (Perkin Elmer). The biotinylated strand was purified using streptavidinecoated magnetic beads (Dynabeads M280-Streptavidine, Dynal AS, Norway). $25 \mu \mathrm{l}$ of Dynabeads were washed once in TES-buffer (TE $+0.1 \mathrm{M} \mathrm{NaCl}$ ), resuspended in $50 \mu \mathrm{l}$ TES and incubated for $30 \mathrm{~min}$ with the $50 \mu \mathrm{PCR}$ reaction at room temperature. The beads were kept in suspension by gently tapping the tubes every $2 \mathrm{~min}$. The biotinylated strand was separated by denaturing for 5 min with $100 \mu \mathrm{l} 0.15 \mathrm{M} \mathrm{NaOH}$ and washing once with TES and once with water. The Dynabeads with the purified biotinylated strand were resuspended in $11 \mu \mathrm{l}$ water. $16 \mathrm{~S}$ rDNA nucleotide sequences were determined from the purified single stranded PCR product by automated sequencing, using ABI PRISM Dye Terminator Cycle Sequencing (Perkin Elmer) with primer 518r (CGTATTACCGCGGCTGCT) (Lane et al. 1985). The accession numbers for the $16 \mathrm{~S}$ rRNA gene sequences of the isolates are presented in Table 1.

Phylogenetic analyses. The phylogenetic trees were constructed by a maximum parsimony method using 
Table 1. Identity of bacterial isolates collected in different sea areas. Also indicated is the \% sequence similarity of the isolates to previously reported organisms. Isolates marked in bold have previously been found to be dominant members of marine bacterioplankton. Bacteria with sequence similarity values to $16 \mathrm{~S}$ rRNA genes as close as (within $1.0 \%$ ) or closer to environmental clones than to reported isolates. Similarity values are based on approximately 400 basepairs. In the taxon column, $\alpha, \beta, \gamma$ : different subclasses of the Proteobacteria; G+: Gram-positive bacteria; FCB: bacteria in the Flexibacter-Cytophaga-Bacteroides phylum

\begin{tabular}{|c|c|c|c|c|}
\hline Isolate & $\begin{array}{c}\text { Accession } \\
\text { no. }\end{array}$ & Closest matching organism & $\begin{array}{c}\text { Similarity } \\
(\%)\end{array}$ & Taxon \\
\hline ANT1 & AF02557 1 & Shewanella frigidimarina; U85902 & 100.0 & $\gamma$ \\
\hline \multirow[t]{2}{*}{ ANT3: } & AF025573 & Pseudomonas azotoformans; D84009 & 99.4 & $\gamma$ \\
\hline & & Clone JAP501; U09827 & 99.3 & $\gamma$ \\
\hline \multirow[t]{2}{*}{ ANT6 } & AF025576 & Pseudoalteromonas sp.; U85862 & 99.2 & $\gamma$ \\
\hline & & Hydrothermal vent clone PVB5; U15114 & 94.4 & $\gamma$ \\
\hline ANT7 & AF025577 & Moraxella sp.; X86614 & 98.8 & $\gamma$ \\
\hline \multirow[t]{2}{*}{ ANT8 } & AF025578 & Pseudoalteromonas tetraodonis; X82139 & 99.4 & $\gamma$ \\
\hline & & Hydrothermal vent clone PVB5; U15114 & 93.1 & $\gamma$ \\
\hline \multirow[t]{2}{*}{ SKA1 } & AF025314 & Colwellia sp; AF056462 & 99.8 & $\gamma$ \\
\hline & & Clone agg53; L10948 & 94.7 & $\gamma$ \\
\hline SKA2 & A.F025315 & Cytophaga lytica; M62796 & 96.4 & FCB \\
\hline SKA3 & AF025316 & Roseobacter gallaeciensis; Y13244 & 97.7 & $\alpha$ \\
\hline SKA4 & AF025317 & Flavobacterium uliginosum; M62799 & 93.9 & $\mathrm{FCB}$ \\
\hline SKA5 & AF025318 & Flavobacterium uliginosum; M62799 & 95.7 & $\mathrm{FCB}$ \\
\hline SKA6 & AF025319 & Hyphomonas johnsonü; AF082791 & 92.9 & $\alpha$ \\
\hline SKA7 & AF025320 & Marine psychrophile; U85886 & 92.5 & FCB \\
\hline SKA8 & AF025321 & Hyphomonas johnsonii; AF082791 & 92.4 & $\alpha$ \\
\hline \multirow[t]{2}{*}{ SKA9 } & A.F025322 & Pseudoalteromonas citrea; AF082563 & 99.2 & $\gamma$ \\
\hline & & Hydrothermal vent clone PVB5; U15114 & 94.8 & $\gamma$ \\
\hline \multirow[t]{2}{*}{ SKA10 } & AF025323 & Roseobacter litoralis; X78312 & 97.2 & $\alpha$ \\
\hline & & Clone SMK735; X78652 & 94.2 & $\alpha$ \\
\hline SKA11 & $\mathrm{AF} 025324$ & Marinomonas vaga; $\times 67025$ & 91.3 & $\gamma$ \\
\hline \multirow[t]{2}{*}{ SKA 12} & AF025325 & Colwellia demingiae; U85844 & 94.6 & $\dot{\gamma}$ \\
\hline & & Clone agg53; L10948 & 93.4 & $\dot{\gamma}$ \\
\hline SKA13 & AF025326 & Alpha proteobacterium: $\mathrm{AB} 015520$ & 87.6 & $\dot{\alpha}$ \\
\hline \multirow{2}{*}{ SKA $14^{\circ}$} & AF025327 & Stenotrophomonas maltophila; X95924 & 98.8 & $\beta$ \\
\hline & & Clone MT3; AF058381 & 99.3 & $\beta$ \\
\hline SKA16 & AF025329 & Vibrio splendidus; $\times 74724$ & 96.7 & $\gamma$ \\
\hline SKA 17 & AF182014 & Arthrobacter histidinolovorans; X83406 & 96.0 & G+ \\
\hline \multirow[t]{2}{*}{ MED1 } & AF025544 & Pseudoalteromonas sp.; AF055816 & 98.5 & $\gamma$ \\
\hline & & Hydrothermal vent clone PVB5; U15114 & 97.0 & $\gamma$ \\
\hline MED2 & AF025545 & Shewanella woodyi; AF003549 & 94.9 & $\gamma$ \\
\hline MED3 & AF025546 & Alteromonas sp.i AB015135 & 98.7 & $\gamma$ \\
\hline \multirow[t]{2}{*}{ MED4 ${ }^{\circ}$} & AF025547 & Pseudoalteromonas sp.; U85855 & 95.5 & $\gamma$ \\
\hline & & Hydrothermal vent clone PVB5; U15114 & 97.0 & $\gamma$ \\
\hline MED5 & AF025548 & Vibrio campbellii; $\times 74692$ & 98.5 & $\gamma$ \\
\hline \multirow[t]{2}{*}{ MED6 } & AF025549 & Roseobacter algicola; $\times 78313$ & 96.5 & $\alpha$ \\
\hline & & ANG clone $1 \mathrm{~g}$; AF022395 & 94.9 & $\alpha$ \\
\hline MED9 & AF025552 & Flavobacterium aquatile; M62797 & 89.2 & $\mathrm{FCB}$ \\
\hline MED 10 & AF025553 & Psychroserpens burtonensis U62913 & 89.7 & $\mathrm{FCB}$ \\
\hline MED11 & AF025554 & Psychroserpens burtonensis; U62912 & 87.5 & $\mathrm{FCB}$ \\
\hline MED12 & AF025555 & Psychrobacter glacincola; U85877 & 99.3 & $\gamma$ \\
\hline \multirow{2}{*}{ MED13 } & AF025556 & Agrobacterium sanguineum; AB021493 & 97.6 & $\alpha$ \\
\hline & & Clone SMK270; X78645 & 93.7 & $\alpha$ \\
\hline \multirow[t]{2}{*}{ MED14 } & AF025557 & Pseudoalteromonas sp.; U85862 & 98.6 & $\gamma$ \\
\hline & & Hydrothermal vent clone PVB5; U15114 & 94.2 & $\gamma$ \\
\hline \multirow[t]{2}{*}{ MED 15 } & AF025558 & Alteromonas macleodii; $\times 82145$ & 93.7 & $\gamma$ \\
\hline & & Hydrothermal vent clone PVB12; U15115 & 93.1 & $\gamma$ \\
\hline MED16 & AF025559 & Brevundimonas subvibrioides; AJ227784 & 98.5 & $\alpha$ \\
\hline MED17 & AF025560 & Erythrobacter longus; M59062 & 97.1 & $\alpha$ \\
\hline MED18 & AF025561 & Polaribacter irgensï; $\mathrm{M} 61002$ & 94.8 & FCB \\
\hline MED 19 & AF025562 & Shewanella pealeana; AF011335 & 97.6 & $\gamma$ \\
\hline MED20 & AF025563 & Haererehalobacter ostenderis; U78786 & 99.0 & $\gamma$ \\
\hline MED21 & AF025564 & Flexibacter sp.; AB008044 & 96.5 & FCB \\
\hline MED22 & AF025565 & Marinocaulobactersp.; AJ227808 & 97.6 & $\alpha$ \\
\hline \multirow[t]{2}{*}{ MED23 } & AF025566 & Alteromonas macleodii; Y18230 & 99.4 & $\gamma$ \\
\hline & & Clone UPB C7; AF111860 & 98.0 & $\gamma$ \\
\hline
\end{tabular}


Table 1 (continued)

\begin{tabular}{|c|c|c|c|c|}
\hline Isolate & $\begin{array}{c}\text { Accession } \\
\text { no. }\end{array}$ & Closest matching organism & $\underset{(\%)}{\text { Similarity }}$ & Taxon \\
\hline \multirow[t]{2}{*}{ MED24 ${ }^{\circ}$} & \multirow[t]{2}{*}{ AF025567 } & Roseobacter litoralis; $\mathrm{X} 78312$ & 94.5 & $\alpha$ \\
\hline & & ANG clone $1 a_{i}$ AF022393 & 95.5 & $\alpha$ \\
\hline MED25 & AF025568 & Marine psychrophile; AF001368 & 91.1 & FCB \\
\hline \multirow[t]{2}{*}{ MED26 } & \multirow[t]{2}{*}{ AF025569 } & Roseobacter litoralis; $\times 78312$ & 96.5 & $\alpha$ \\
\hline & & Clone SMK735; X78652 & 95.3 & $\alpha$ \\
\hline \multirow[t]{2}{*}{ MED27 } & \multirow{2}{*}{ AF025570 } & Pseudoalteromonas aurantia; X82135 & 99.6 & $\gamma$ \\
\hline & & Hydrothermal vent clone PVB5; U15114 & 95.7 & $\gamma$ \\
\hline MED28 & AF182015 & Flexibacter sp; AB008044 & 96.0 & FCB \\
\hline \multirow[t]{2}{*}{ AND1 } & \multirow[t]{2}{*}{$\mathrm{AF} 025957$} & Alteromonas macleodii; X82145 & 98.6 & $\gamma$ \\
\hline & & Clone DCM-ATT-9; AF114509 & 98.2 & $\gamma$ \\
\hline AND2 & AF025958 & Halomonas meridiana; M93356 & 98.3 & $\gamma$ \\
\hline AND4 & AF025960 & Vibrio campbellii; X74692 & 97.8 & $\gamma$ \\
\hline AND5 & AF025961 & Marinobactersp.; AJ000647 & 99.0 & $\gamma$ \\
\hline ANTDE & $A \Gamma 025962$ & Cytophaga marinoflava; M58770 & 95.7 & FCB \\
\hline SCB8 & Z31657 & Vibrio splendidus; $\mathrm{X74724}$ & 98.0 & $\gamma$ \\
\hline SCB 11 & $\mathrm{Z31658}$ & Aeromonas hydrophila; X87271 & 90.7 & $\gamma$ \\
\hline \multirow[t]{2}{*}{ SCB21 } & \multirow[t]{2}{*}{ U63998 } & Sphingomonas sp.; AJ011014 & 98.6 & $\alpha$ \\
\hline & & Clone ASB003; AB010598 & 95.6 & $\alpha$ \\
\hline \multirow[t]{2}{*}{ SCB22 } & \multirow[t]{2}{*}{ U63999 } & Marinobacter sp.; AJ000647 & 96.0 & $\gamma$ \\
\hline & & Clone OM59; U70695 & 96.7 & $\gamma$ \\
\hline SCB23 & $\mathrm{U} 64000$ & Chromohalobacter marismortui; X87219 & 93.2 & $\gamma$ \\
\hline \multirow[t]{2}{*}{ SCB24 } & \multirow[t]{2}{*}{ U64001 } & Pseudomonas stutzeri; U25280 & 99.8 & $\gamma$ \\
\hline & & Clone TRS3; AJ005873 & 98.3 & $\gamma$ \\
\hline \multirow[t]{2}{*}{$\mathrm{SCB} 25$} & U64002 & Mesorhizobium amorphae; AF041442 & 97.2 & $\alpha$ \\
\hline & & Clone LRE10; AJ232884 & 95.6 & $\alpha$ \\
\hline SCB26 & U64003 & Erythrobacter longus; M59062 & 96.3 & $\alpha$ \\
\hline & & Clone GKS69; AJ224989 & 94.3 & $\alpha$ \\
\hline $\mathrm{SCB} 27^{*}$ & $\mathrm{U} 64004$ & Stenotrophomonas maltophila; AJ131114 & 99.0 & $\beta$ \\
\hline & & Clone MT3; AF058381 & 98.4 & $\beta$ \\
\hline SCB28* & U64005 & Roseobacter sp.; AF022392 & 97.0 & $\alpha$ \\
\hline & & Clone GAC-2; AF007250 & 100.0 & $\alpha$ \\
\hline SCB29 & $\mathrm{U} 64006$ & Vibrio mediterranei; $\times 74710$ & 97.9 & $\gamma$ \\
\hline SCB31* & $\mathrm{U} 64008$ & Roseobacter gallaeciensis; Y13244 & 99.5 & $\alpha$ \\
\hline & & Egg clone D39; AF022397 & 98.9 & $\alpha$ \\
\hline SCB32 & U64009 & Sulfitobacter pontiacus; Y13155 & 98.3 & $\alpha$ \\
\hline SCB33 & U64010 & Alteromonas sp.; AB015135 & 99.8 & $\gamma$ \\
\hline & & Clone 400m-ATT-5; AF114507 & 98.2 & $\gamma$ \\
\hline SCB34 & U64011 & Roseobacter algicola; X78315 & 96.3 & $\alpha$ \\
\hline & & ANG clone $1 \mathrm{a}_{i}$ AF022393 & 94.9 & $\alpha$ \\
\hline SCB35 & U64012 & Pseudoalteromonas nigrifaciens; X82146 & 97.7 & $\gamma$ \\
\hline SCB36 & U64013 & Psychroserpens burtonensis; Y17132 & 90.5 & FCB \\
\hline SCB37 & U64014 & Polaribacter irgensii; M61002 & 91.7 & FCB \\
\hline SCB38 & U64015 & Cytophaga columnaris; AB016515 & 89.7 & FCB \\
\hline SCB39 & U64016 & Vibrio tubiashi; $X 74725$ & 97.1 & $\gamma$ \\
\hline SCB40 & U64017 & Marine bacterium; AJ002569 & 98.0 & FCB \\
\hline SCB $41^{\circ}$ & U64018 & Flavobacterium uliginosum; M62799 & 93.0 & FCB \\
\hline & & Clone $\mathrm{KC} 429 ; \mathrm{AB} 022483$ & 97.4 & $\mathrm{FCB}$ \\
\hline SCB42 & U64019 & Octadecabacter antarcticus; U14583 & 97.0 & $\alpha$ \\
\hline SCB43* & U64020 & Pseudoalteromonas carrageenovora; X82136 & 99.6 & $\gamma$ \\
\hline & & Clone 400m-ATT-16; AF114522 & 98.8 & $\gamma$ \\
\hline SCB44 & U64021 & Polaribacter irgensii; M61002 & 96.2 & FCB \\
\hline $\mathrm{SCB} 45^{\circ}$ & $\mathrm{U} 64022$ & Halomonas campusalis; AF054286 & 90.3 & FCB \\
\hline & & Clone T39; Z93986 & 93.7 & $\mathrm{FCB}$ \\
\hline SCB46 & U64023 & Flexibacter sp.; AB008044 & 95.2 & $\mathrm{FCB}$ \\
\hline $\mathrm{SCB} 47$ & U64024 & Vibrio splendidus; $\times 74724$ & 98.3 & $\gamma$ \\
\hline SCB48* & U64025 & Roseobacter gallaeciensis; Y13244 & 94.9 & $\alpha$ \\
\hline & & Egg clone D39; AF022397 & 95.0 & $\alpha$ \\
\hline SCB49 & U64026 & Polaribacter irgensii; M61002 & 87.1 & $\mathrm{FCB}$ \\
\hline SCB50 & U64027 & Marinomonas vaga; $\times 67025$ & 96.5 & $\gamma$ \\
\hline SCB51 & AF026390 & Vibrio campbellii; $\times 74692$ & 97.6 & $\gamma$ \\
\hline SCB52 & AF026391 & Burkholderia solanacearum; S55002 & 91.8 & $\beta$ \\
\hline & & Clone OM156; U70706 & 92.6 & $\beta$ \\
\hline
\end{tabular}


Table 1 (continued)

\begin{tabular}{|c|c|c|c|c|}
\hline Isolate & $\begin{array}{c}\text { Accession } \\
\text { no. }\end{array}$ & Closest matching organism & $\begin{array}{c}\text { Similarity } \\
(\%)\end{array}$ & Taxon \\
\hline SCB53 & AF026392 & Beta proteobacterium; AF035052 & 93.4 & $\beta$ \\
\hline \multirow[t]{2}{*}{ SCB56 } & AF052601 & Alteromonas macleodii; Y18234 & 98.9 & $\gamma$ \\
\hline & & Clone SUR-ATT-13; AF114497 & 98.0 & $\dot{\gamma}$ \\
\hline SCB57 & AF182016 & Microbacterium sp.; AB010618 & 95.0 & $\mathrm{G}+$ \\
\hline \multirow[t]{2}{*}{ SCB58 } & AF182017 & Kocuria rhizophila; Y16264 & 95.7 & $\mathrm{G}+$ \\
\hline & & CloneMT2; AF058372 & 97.8 & $\mathrm{G}+$ \\
\hline SCB59 & AF182018 & Sulfitobacter pontiacus; Y13155 & 99.8 & $\alpha$ \\
\hline \multirow[t]{2}{*}{ BAL2 ${ }^{\circ}$} & U63934 & Rhodobacter azotoformans; D70846 & 95.5 & $\alpha$ \\
\hline & & Clone LRS3; AJ232852 & 96.6 & $\alpha$ \\
\hline BAL3 & U63935 & Brevundimonas sp.; AJ227801 & 99.5 & $\alpha$ \\
\hline BAL4 & U63936 & Flavobacterium sp.i U85890 & 92.0 & FCB \\
\hline BAL5 & U63937 & Sphingomonas sp.; U37345 & 98.1 & $\alpha$ \\
\hline BAL6 & AF182023 & Unid. actinomycete; AB015562 & 97.1 & $\mathrm{G}+$ \\
\hline BAL7 & AF182024 & Acinetobacter radioresistens; X81666 & 98.6 & $\gamma$ \\
\hline \multirow[t]{2}{*}{ BAL9 } & U63938 & Flavobacterium sp.; AB008041 & 99.5 & FCB \\
\hline & & Clone LBS17; AJ232835 & 93.8 & FCB \\
\hline BAL10 & AF182019 & Sphingomonas subarctica; X94102 & 97.5 & $\alpha$ \\
\hline BAL11 & U63939 & Rhizomonas suberifaciens; D13737 & 97.7 & $\alpha$ \\
\hline BAL13 & U63940 & Flavobacterium sp.; U85889 & 95.7 & FCB \\
\hline \multirow[t]{2}{*}{ BAL15 } & U63941 & Janthinobacterium Lvidum; Y08846 & 99.4 & $\beta$ \\
\hline & & Clone CTHB-18; AF067655 & 99.2 & $\beta$ \\
\hline \multirow[t]{2}{*}{ BAL16 ${ }^{\circ}$} & U63942 & Pseudomonas megulae; AF074383 & 97.1 & $\gamma$ \\
\hline & & Clone NB1-g; AB013828 & 97.3 & $\gamma$ \\
\hline BAL17 & U63943 & Cytophaga aquatile; M58764 & 95.0 & FCB \\
\hline \multirow[t]{2}{*}{ BAL18* } & U63944 & Pseudomonas veronii; AF064460 & 99.8 & $\gamma$ \\
\hline & & Clone TRS26; AJ005872 & 99.6 & $\gamma$ \\
\hline \multirow[t]{2}{*}{ BAL22* } & U63946 & Flavobacterium aquatile; M62797 & 91.8 & FCB \\
\hline & & Clone LBS17; AJ232835 & 92.2 & FCB \\
\hline BAL23 & U63947 & Pseudomonas gessardi; AF074384 & 99.8 & $\gamma$ \\
\hline BAL25 & U63948 & Shewanella baltica; AJ000216 & 97.9 & $\gamma$ \\
\hline \multirow{2}{*}{ BAL27 $7^{\circ}$} & U63949 & Rhodobacter azotoformans; D70847 & 95.4 & $\alpha$ \\
\hline & & Clone LRS3; AJ232852 & 96.3 & $\alpha$ \\
\hline BAL29 & U63950 & Marine psychrophile; U85891 & 92.2 & FCB \\
\hline \multirow[t]{2}{*}{ BAL31 } & U63951 & Pseudomonas anguilliseptica; X99541 & 97.3 & $\gamma$ \\
\hline & & Clone LRE23; AJ232872 & 96.1 & $\gamma$ \\
\hline \multirow{2}{*}{ BAL34 } & U63952 & Agrobacterium sanguineum; AB021493 & 98.7 & $\alpha$ \\
\hline & & Clone TRS1; AJ006014 & 93.9 & $\alpha$ \\
\hline BAL37 & U63953 & Alcaligenes sp.; AJ002802 & 97.7 & $\beta$ \\
\hline \multirow[t]{2}{*}{ BAL38 " } & U63954 & Flavobacterium aquatile; M62797 & 92.0 & $\mathrm{FCB}$ \\
\hline & & Clone LBS17; A.J232835 & 92.3 & $\mathrm{FCB}$ \\
\hline \multirow[t]{2}{*}{ BAL39* } & U63955 & Flavobacterium heparinum; M11657 & 94.4 & FCB \\
\hline & & Clone JAP411; U09780 & 96.4 & $\mathrm{FCB}$ \\
\hline \multirow[t]{2}{*}{ BAL $40^{\circ}$} & U63956 & Sphingomonas terrae; D 13727 & 95.3 & $\alpha$ \\
\hline & & Clone ASB003; AB010598 & 94.3 & $\alpha$ \\
\hline \multirow[t]{2}{*}{ BAL43 } & U63957 & Zoogloea ramigera; X74915 & 95.6 & $\alpha$ \\
\hline & & Clone SJA-53; AJ009467 & 93.8 & $\alpha$ \\
\hline BAL44 & U63958 & Sphingomonas capsulata; D16147 & 93.6 & $\alpha$ \\
\hline BAL45 & U63959 & Sphingomonas sp.; X94098 & 97.5 & $\alpha$ \\
\hline BAL46 & U63960 & Sphingomonas sp.; U52146 & 96.3 & $\alpha$ \\
\hline \multirow[t]{2}{*}{ BAL47* } & U63961 & Rhodoferax fermentans; D16211 & 92.3 & $\beta$ \\
\hline & & Clone 4-4; AJ011158 & 96.4 & $\beta$ \\
\hline BAL48 & U63962 & Sphingomonas sp.; U52146 & 97.6 & $\alpha$ \\
\hline & & Clone LRE17; AJ232863 & 95.6 & $\alpha$ \\
\hline BAL49 & AF182020 & Marine psychrophile; U85891 & 95.4 & FCB \\
\hline BAL50 & AF182021 & Cytophaga sp.; X85210 & 93.5 & $\mathrm{FCB}$ \\
\hline & & Clone LBS24; AJ232834 & 93.3 & $\mathrm{FCB}$ \\
\hline BAL51 & AF182022 & Brevundimonas sp.; A.J227801 & 100.0 & $\alpha$ \\
\hline BAL52 & AF182025 & Hyphomonas sp.; M83812 & 86.8 & $\alpha$ \\
\hline BAL53 & AF182026 & Sphingomonas yanoikuyae; D16145 & 92.1 & $\alpha$ \\
\hline BAL54 & AF 182027 & Sphingomonas yanoikuyae; D16145 & 97.7 & $\alpha$ \\
\hline BAL55 & AF182028 & Pseudomonas putida; D37923 & 98.5 & $\gamma$ \\
\hline
\end{tabular}


PAUP 3.0 for the Macintosh. The trees were calculated from the nucleotide positions approximately corresponding to the positions 130 to 500, Escherichia coli numbering. Our isolate sequences were compared to existing procaryotic sequences in the GenBank using the 'fasta' command in the GCG-package. Closest matching clones were obtained by the similarity rank command in RDP (Ribosomal Database Project).

DNA-DNA relatedness. Cross hybridization between the different bacteria was assessed by hybridization of extracted DNA. The DNA from the different isolates was blotted onto hybridization membranes according to the manufacturer (Hybond-N, Amersham), using a slot blot apparatus (GIBCO BRL). The membranes were then hybridized towards single whole yenume proves preparted by labelling the genomic DNA prepared from each of the different bacteria with a nick translation kit (Promega) and $[\alpha-$ ${ }^{32}$ PJdATP (Amersham) (Pinhassi et al. 1999, 1997). The hybridization signal was detected and quantified using a PhosphorImager (Molecular Dynamics).

\section{RESULTS}

Over a number of years we collected approximately 500 bacterial isolates from the Baltic Sea (BAL), Mediterranean (MED), Southern California Bight (SCB), Skagerrak (SKA), Weddell Sea ice (ANT) and the Andaman Sea (AND). Based on differences in colony morphology we selected 215 isolates to be sequenced, out of which 128 different isolates are included in the present analysis (Table 1). The remaining sequenced isolates were replicates or near identical and were omitted for the sake of clarity. The extensive list in Table 1 includes 26 species that have been demonstrated to be dominant components of the community DNA at different locations. For example SCB8 and SCB11 showed bloom occurrence in the waters off Scripps Pier (Rehnstam et al. 1993), SCB37 and SCB54 achieved high numbers in 2 seawater mesocosm experiments (Pinhassi et al. 1999), and BAL8 and BAL11 occurred at high abundance during different times of the year in the Baltic Sea (Pinhassi et al. 1997).

Ideally bacterial systematics should rely on both genotypic and phenotypic characteristics, i.e. a polyphasic approach (Wayne et al. 1987, Murray et al. 1990). For this study, however, we elected to use only 16S rRNA sequence information since this would allow a comparison to environmental clones that, due to the lack of phenotypic traits, have been assigned taxonomic affiliation solely on $16 \mathrm{~S}$ rRNA sequence information. Partial sequences of the $16 \mathrm{~S}$ rRNA gene (350 to 400 bases) were used in the analysis. Therefore a comparison of the variability of the full-length sequence and the par- tial sequence was made to ensure that the partial sequences were long enough to resolve taxonomic differentiation between isolates. Sequences from closely related isolates of each of the Cytophaga, $\alpha$-Proteobacteria and $\gamma$-Proteobacteria groups were aligned and the corresponding similarity values were recorded. Furthermore, sequences were compared between groups, thus generating alignments with lower match. The resulting dataset from 16 comparisons was evaluated using a linear regression showing a high degree of correlation between full length and partial sequences $\left(\mathrm{r}^{2}=\right.$ $0.975, p<0.005)$. On average the difference in similarity was less than $1 \%$. A series of measurements on the crosshybridization between different isolates was carried out to establish a level of sequence similarity required to tell different species and genera apart From the results we could compile the degree of DNADNA relatedness versus the similarity between the respective 16S rRNA gene sequences (Fig. 1), although a few outliers were present in the dataset. From this graph, and similar data from previous compilations (Devereux et al. 1990, Amann et al. 1992, Stackebrandt \& Goebel 1994), we decided that isolates with a sequence similarity of $\geq 97 \%$ were representatives of the same species. Furthermore, a similarity between 97 and $93 \%$ would represent identity at the genus level but difference at the species level. The minimum level of sequence similarity chosen for our tentative genus designation ( $>93 \%$ ) was a conservative limit based on the taxonomic discussion of genus identity among 3 different bacterial groups (Devereux et al. 1990, Dobson et al. 1993, Wiik et al. 1995).

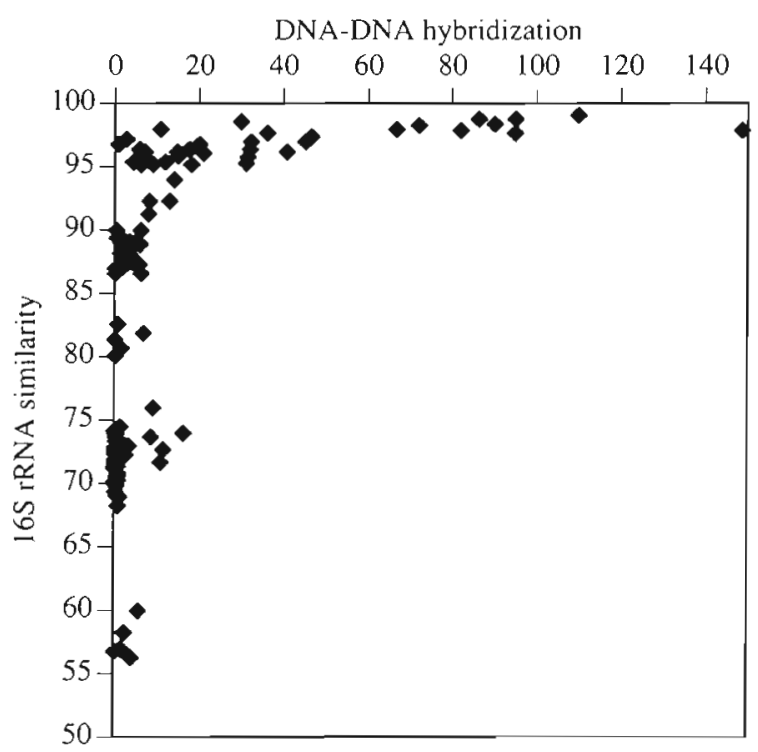

Fig. 1. Comparison of DNA-DNA hybridization between different isolates and the corresponding sequence similarity of partial 16S rRNA genes 
Table 2. Sequence similarity of the isolates to closest matching relative in the data bank. Distribution of isolates from the different divisions among sequence similarity values representing new genus $(<0.93)$, new species within previously characterized genus $(0.93$ to 0.97$)$, and previously characterized species $(>0.97)$

\begin{tabular}{|lrrrr|}
\hline Bacterial division & \multicolumn{3}{c}{$\begin{array}{c}\text { Sequence similarity to } \\
\text { previously reported bacteria } \\
>0.97\end{array}$} & $\begin{array}{c}\text { 0.93-0.97 } \\
\text { isolates }\end{array}$ \\
\hline$\gamma$-Proteobacteria & $78 \%$ & $18 \%$ & $4 \%$ & 46 \\
$\alpha$-Proteobacteria & $55 \%$ & $33 \%$ & $12 \%$ & 40 \\
Flexibacter-Cytophaga-Bacteroides & $7 \%$ & $43 \%$ & $50 \%$ & 30 \\
$\beta$-Proteobacteria & $57 \%$ & $14 \%$ & $29 \%$ & 7 \\
Gram-positive bacteria & $25 \%$ & $75 \%$ & 0 & 4 \\
A.ll divisions & $52 \%$ & $30 \%$ & $18 \%$ & 126 \\
\hline
\end{tabular}

The sequence similarity values of our isolates to previously reported organisms are presented in Table 1. Half of our isolates showed a $16 \mathrm{~S}$ rRNA gene sequence similarity of $<97 \%$ to previously reported sequences, and $18 \%$ showed similarities ranging from 82 to $93 \%$ (Table 2). These low similarity values indicate novelty at the genus level. The Flexibacter-Cytophaga-Bacteroides phylum appeared as the least known taxon, whereas the $\gamma$-Proteobacteria generally showed high similarity values to known bacteria.

Environmental clones related to our isolates were included in Table 1 when the sequence similarity suggested a relationship above the tentative genus level. This was the case for 51 isolates, of which 17 were more similar to clones than to cultured bacteria. For example, SCB28 was $100 \%$ similar to environmental clone GAC2 while being $97 \%$ similar to a Roseobacter isolate.

The $\alpha$-Proteobacteria. Fig. 2 shows a phylogenetic tree of the isolated $\alpha$-Proteobacteria. A majority of these isolates were divided into 2 separate lineages, largely representing the genera Roseobacter and Sphingomonas. A prominent feature was the lack of Roseobacter isolates in the Baltic Sea, and the lack of bacteria with origin other than the Baltic Sea within the Sphingomonas. Although in a distant branch, the Southern California Bight isolate SCB21 and the Baltic isolate, BAL40, also produced high similarity to known Sphingomonas. Among the Roseobacter, isolates were found from the Southern California Bight, Mediterranean Sea, and Skagerrak. A separate cluster was also formed by 3 different Hyphomonas species from the Skagerrak. Near identical sequences of bacteria collected in different sea areas were found in 2 cases: the Roseobacter isolates from the Southern California Bight (SCB34) and the Mediterranean Sea (MED6) were close to identical and from the same sea areas, and the Erythrobacter isolates SCB26 and MED17 were $99.1 \%$ similar.

The $\gamma$-Proteobacteria. Almost half of our isolates belonged to the $\gamma$-Proteobacteria (Fig. 3). Two-thirds of these isolates clustered into 5 major groups representing the genera Vibrio, Pseudoalteromonas, Alteromonas, Shewanella, and Pseudomonas. In the genera Pseudoalteromonas and Alteromonas, closely related bacteria from several different sea areas were found. Within the genera Vibrio, Shewanella, and Pseudomonas, isolates from different sea areas were found, but the heterogeneity within the genera was higher and no identical isolates originating from different sea areas were found. A striking feature was the lack of isolates from the Baltic Sea among the genera Vibrio, Pseudoalteromonas, and Alteromonas. The Baltic isolates were instead found among Pseudomonas, Shewanella, and the Acinetobacter. The genus Acinetobacter was found together with a number of halotolerant and psychrophilic bacterial genera in a deeply rooted cluster, possibly related at the family level.

The Flexibacter-Cytophaga-Bacteroides phylum. The bacterial isolates affiliated with this phylum were distributed among 4 major lineages (Fig. 4). The bacteria from the Baltic Sea were mainly divided into 2 major clusters separated from bacteria of other geographic origins. One lineage represented bacteria close to Flexibacter and the other represented a subcluster of the Cytophaga-Flavobacterium branch. Several of the Southern California Bight isolates clustered with Mediterranean isolates, although only 1 instance of close relationship between the Southern California Bight and the Mediterranean was found in this group: SCB46 and MED21 showing a sequence similarity of $99.4 \%$. Three other Southern California Bight isolates (SCB36, -37, -49) formed a loose cluster with Polaribacter sp. as the closest neighbour. The isolates from the Mediterranean clustered separately. Specific lineages separated at the genus level were also characteristic of 7 of the 8 isolates from the Southern California Bight.

The Gram-positive and $\beta$-Proteobacteria. Only a few Gram-positive isolates were found in the different sea areas (Table 2, Fig. 5). The isolates belonging to the $\beta$-Proteobacteria (Fig. 5) were also few, but may represent biogeochemically interesting species, since several of them are reported to have the ability to perform nitrogen fixation (Malik \& Schlegel 1981).

\section{DISCUSSION}

In this study the diversity of bacteria isolated on solid media from a number of different sea areas was investigated by means of $16 \mathrm{~S}$ rRNA gene sequencing. The 


\section{$\alpha$-Proteobacteria}

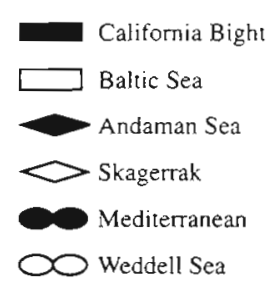

Fig. 2. Phylogenetic tree based on partial $16 \mathrm{~S}$ rRNA gene sequences for bacterial isolates belonging to the $\alpha$-Proteobacteria collected in different sea areas. The maximum parsimony tree was rooted with the Gram-positive Microbacterium lacticum

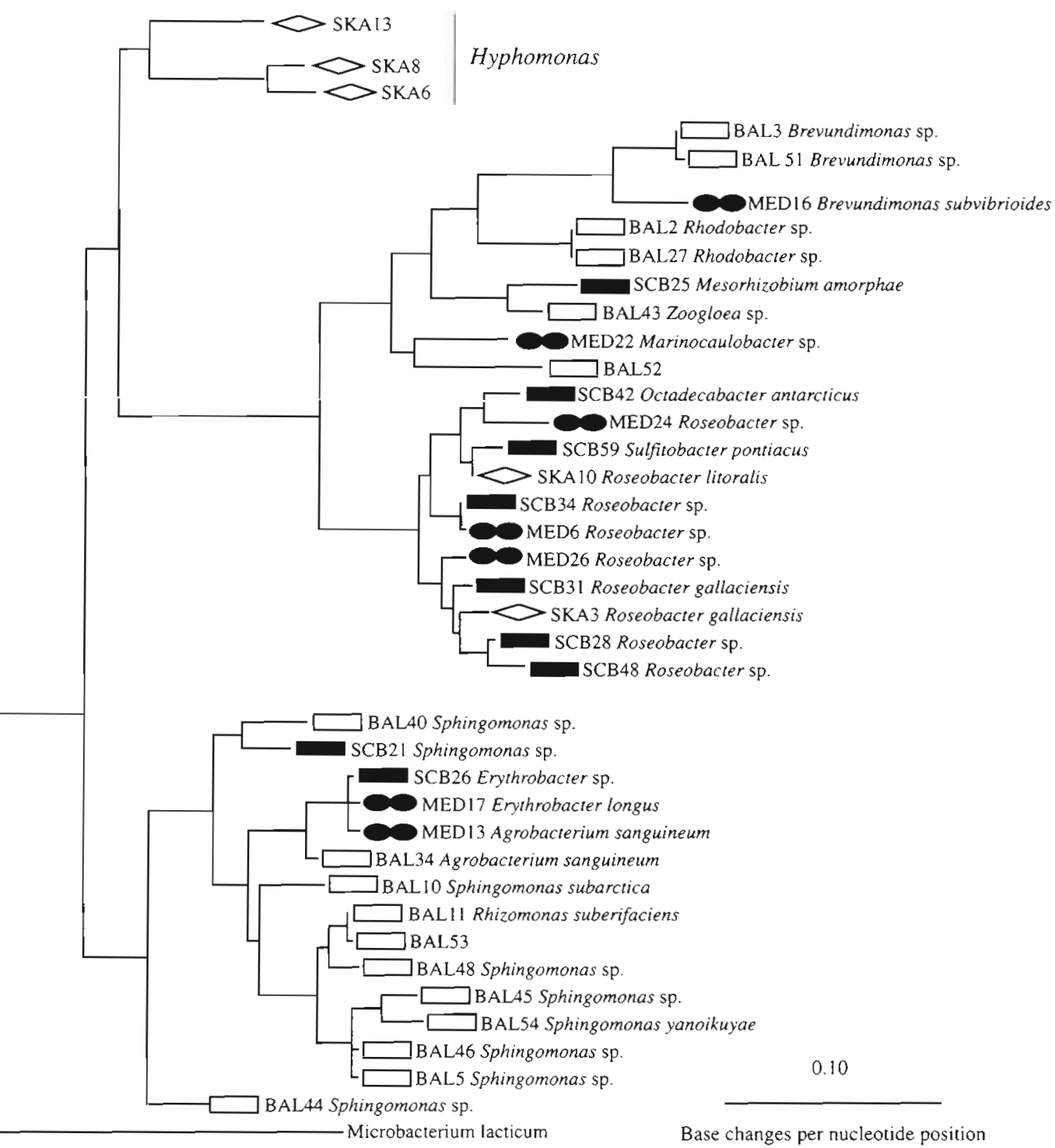

phylogenetic analyses revealed a considerable species diversity among the isolated bacteria, with sequence similarity values of the isolates to previously reported sequences ranging from 82 to $100 \%$ (Table 1). Notably, half of the isolates showed a sequence similarity of $<97 \%$ to previously reported sequences, with a high proportion (18\%) having sequence similarities ranging from 82 to $93 \%$ (Table 2 ). These low similarity values indicate novelty at the genus level, and even at the level of new families (Devereux et al. 1990). The incidence of poorly characterized taxa was highest for members of the Flexibacter-Cytophaga-Bacteroides phylum, whereas the $\gamma$-Proteobacteria generally showed high similarity values to known bacteria. These obser- vations are in agreement with other recent reports on the prevalence of novel bacteria among bacteria in culture (Rehnstam et al. 1993, Bowman et al. 1997, Kalmbach et al. 1997. Pinhassi et al. 1997, Suzuki et al. 1997). In a collection of isolates from Pacific waters off the coast of Oregon, a majority of the isolates showed sequence similarities, ranging from 84 to $97 \%$, to previously reported nearest neighbours in the RDP database (Suzuki et al. 1997). Similarly, in a study of the phylogenetic diversity among bacterial isolates from Antarctic sea ice, 26 phylogenetic groups putatively equivalent to bacterial genera were found, including several apparently novel genera (Bowman et al. 1997). Thus, the great bacterial diversity in the marine envi- 


\section{$\gamma$-Proteobacteria}

Fig. 3. Phylogenetic tree based on partial $16 \mathrm{~S}$ rRNA gene sequences for bacterial isolates belonging to the $\gamma$-Proteobacteria collected in different sea areas. The maximum parsimony tree was rooted with the Gram-positive Microbacterium lacticum
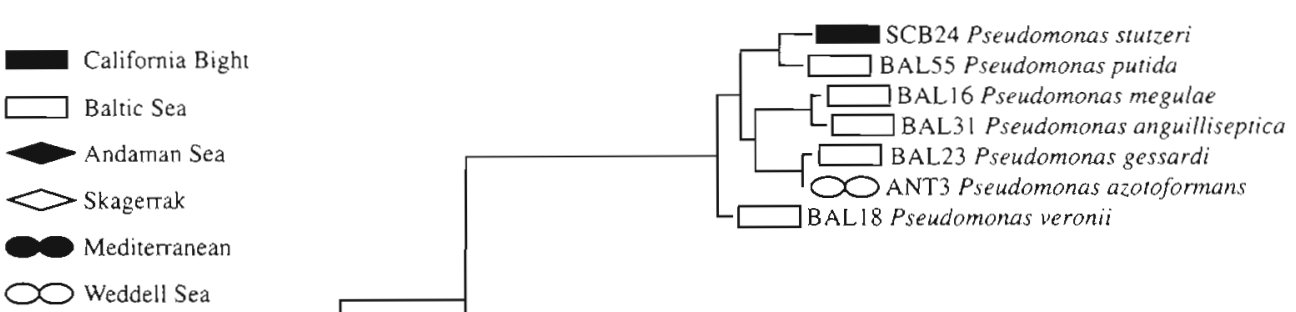
(a)

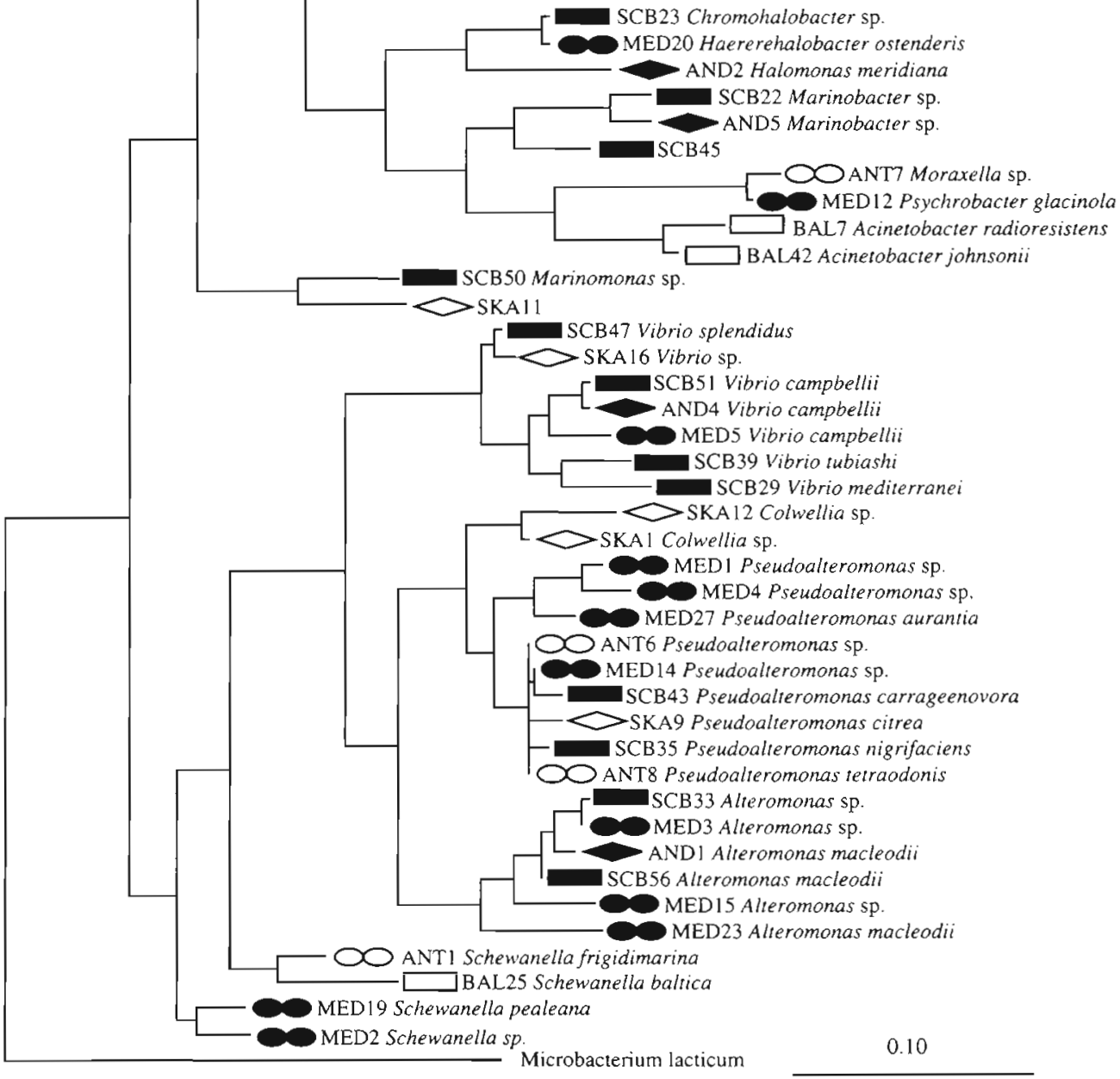

Base changes per nucleotide position

ronment found by culture-independent techniques can be extended using information from live and functional bacteria,

One-third of the bacteria in this study belonged to the $\gamma$-Proteobacteria, and a significant proportion of the isolates belonged to the $\alpha$-Proteobacteria and the Flexibacter-Cytophaga-Bacterioides phylum. The predominance of $\gamma$-Proteobacteria in the sequence databases as well as in other work on bacteria in culture (Mullins et al. 1995, Bowman et al. 1997, Suzuki et al. 1997) is in contrast to their scarcity when assessed by culture-independent methods (Giovannoni et al. 1990, DeLong et al. 1993, Fuhrman et al. 1993). In our experience $\gamma$-Proteobacteria rapidly form conspicuous colonies, while several of the $\alpha$-Proteobacteria grow slowly and produce small, nondescript colonies easy to overlook on agar plates. This could be one explanation for the abundance of $\gamma$-Proteobacteria in culture collections. The poor match to reported sequences of our bacteria matching Cytophaga relatives was, however, unexpected, given the interest in the enzymatic versatility of this taxon, as well as their often vivid coloration.

A number of the isolated bacteria have previously been shown to occupy significant fractions of the bac- 


\section{Flexibacter-Cytophaga-Bacteroides}

Fig. 4. Phylogenetic tree based on partial 16S rRNA gene sequences for bacterial isolates belonging to the Flexibacter-Cytophaga-Bacteroides phylum collected in different sea areas. The maximum parsimony tree was rooted with the Grampositive Microbacterium lacticum
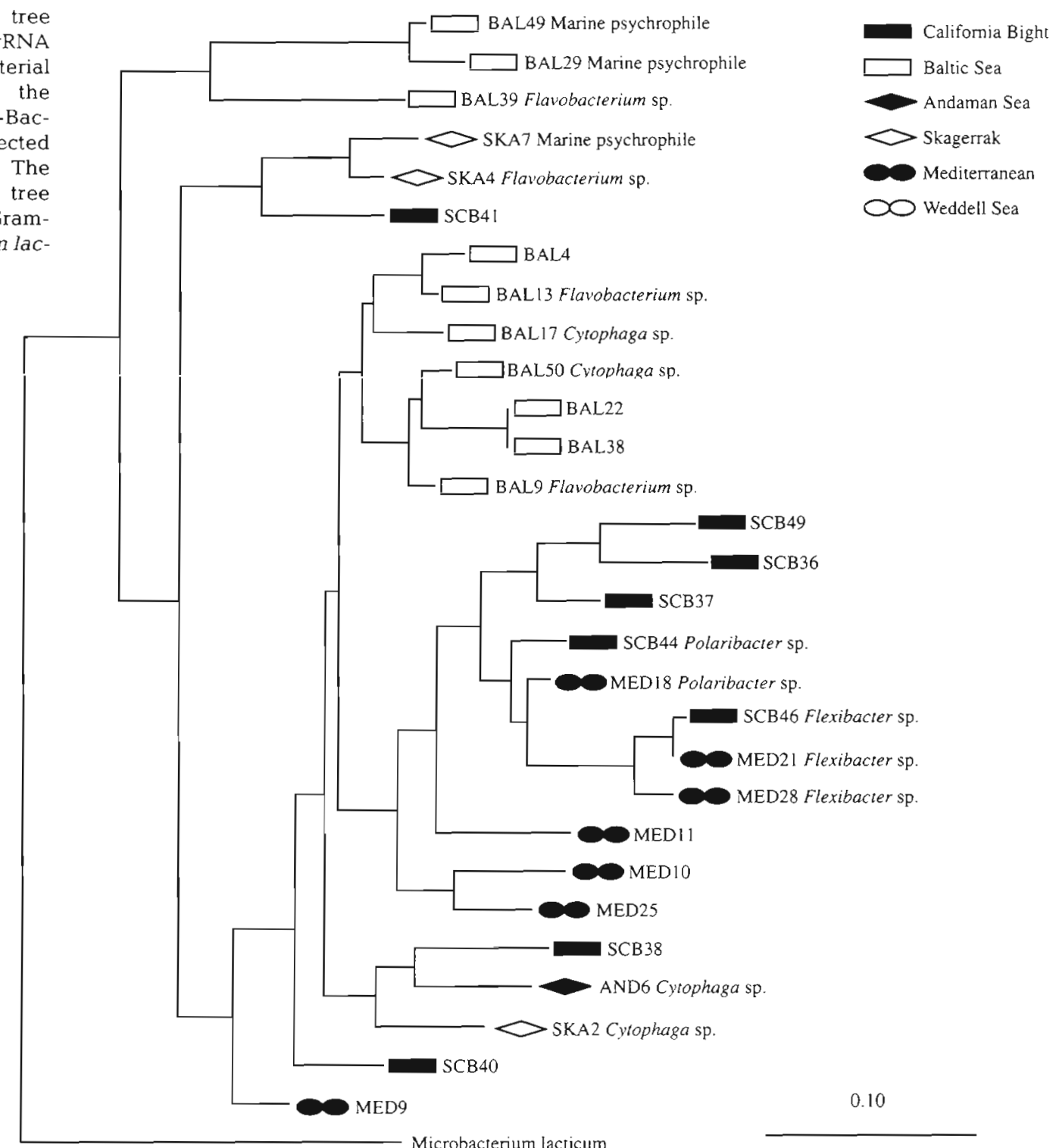

Microbacterium lacticum

Base changes per nucleotide position

terioplankton in different environments (Rehnstam et al. 1993, Pinhassi et al. 1997, 1999, Pinhassi \& Hagstrom 2000, in this issue) (see Table 1). It was therefore interesting to investigate the possible degree of similarity of the isolates to organisms detected through environmental cloning. This search showed that $13 \%$ of the isolates showed higher sequence similarities to cloned sequences than to cultured bacteria. This value is in line with the data presented by Suzuki et al. (1997) comparing the sequences of 26 different isolated bacteria to 25 sequences obtained by cloning from the same seawater sample. Their comparison revealed that
3 of the sequences were shared by isolates and clones (Suzuki et al. 1997). Similar results were found by Chandler et al. (1997), who showed that the bacterial isolates accounted for $11 \%$ of the environmental clones, although the number of different clones was 5 times the number of isolates (Chandler et al. 1997). Agreement between cultivation and direct cloning techniques have also been demonstrated for the methanogenic community in soil (Großkopf et al. 1998). Thus, it appears likely that increased efforts to cultivate bacteria from the environment will yield increasing insights into the indigenous bacterial diversity. 


\section{$\beta$-Proteobacteria \& Gram positives}

Fig. 5. Phylogenetic tree based on partial $16 \mathrm{~S}$ rRNA gene sequences for bacterial isolates belonging the $\beta$-Proteobacteria and to a few Gram-positive bacteria collected in different sea areas. The maximum parsimony tree was rooted with a Gramnegative Flexibacter species

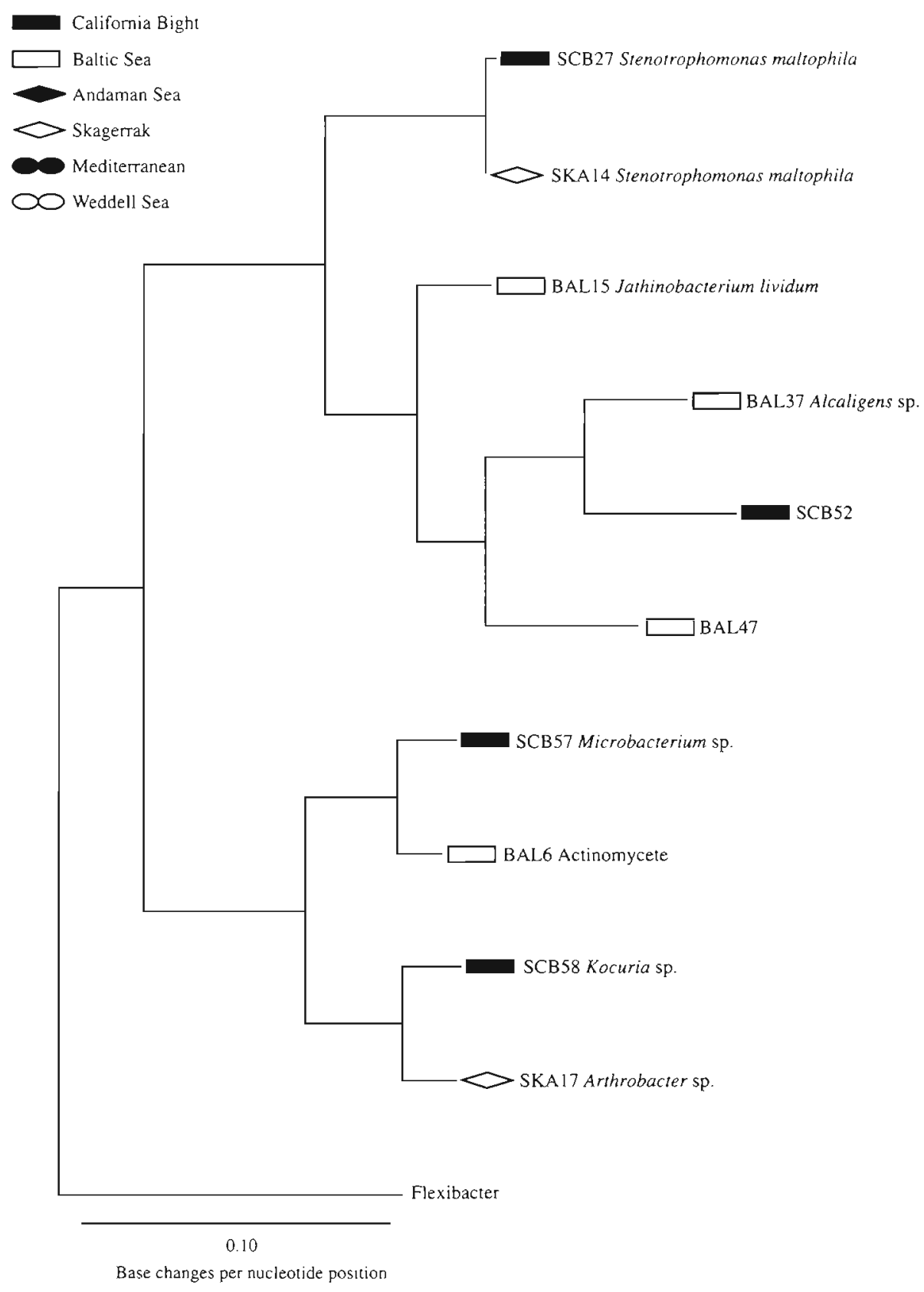

\section{Geographic distribution of the isolates}

Bacterioplankton community composition in different sea areas was studied by Lee \& Furhman (1991). Using a whole community DNA hybridization technique, they found a low similarity between Pacific Ocean, Long Island Sound and Caribbean Sea samples $(<16 \%)$. This result suggested that few bacterioplankton species would be distributed worldwide. However near identical environmental clones from different sea areas have subsequently been reported by DeLong (1992), Fuhrman et al. (1993), and Mullins et al. (1995), although they in no case represented the majority of the studied clones. Also, Bowman et al. (1997) found nearly identical isolates in Antarctic sea ice and temperate environments. In the present study, closely related isolates most often originated from the same geographic area. Most genera could be found in the Southern California Bight, the Skagerrak and the northwest Mediterranean, although represented by 
different species. This is illustrated by the isolates belonging to the genus Pseudoalteromonas, which showed a high degree of similarity between different sea areas, and the Vibrio species that seem more specific to each sea area. In the phylogenetic trees the Baltic Sea isolates often formed separate lineages, representing different genera. It is likely that the lack of 'marine' (salt tolerant) genera can be attributed to the low salinity in the northern Baltic $(<10 \%)$. Species of Roseobacter and Vibrio as well as Alteromonas all have a salt requirement for growth. In their place members of the genera Pseudomonas, Shewanella, and Sphingomonas are common in the Baltic. The presence of the first 2 genera has been demonstrated previously (Höfle \& Brettar 1995, 1996). In the Baltic the saiinity gradient is a very stable property and the different community composition (at the genus level) is therefore not unexpected. Instead it is tempting to suggest that other estuarine environments may differ from oceanic environments in the same manner. The Weddell Sea ice represents a seemingly isolated habitat, and may not be expected to harbour bacteria that would occur in other sea areas. However, the Baltic isolate BAL23 belonging to the genus Pseudomonas was almost identical to the Weddell Sea ice isolate ANT3, and together with a second close couple related to Shewanella served to link these 2 remote sea areas. Also, within the genus Pseudoalteromonas, 2 isolates, 1 from the Southern California Bight and 1 from the Mediterranean Sea, were found to be closely related to a Weddell Sea ice isolate.

\section{Divergence and persistence of bacterial species}

Widespread species distribution between different sea areas raises the question of how this 'homogeneity' among certain genera is maintained. In order to answer this question several complex issues, such as spreading of surface seawater, mechanisms for transfer of genetic material and the resulting population genetics, have to be considered. Although significant changes in the bacterioplankton species composition occur at various temporal and spatial scales, the persistence of specific bacteria between consecutive years seems to be a general phenomenon (Lee \& Fuhrman 1991, Rehnstam et al. 1993, Höfle \& Brettar 1995, Faude \& Höfle 1997, Ziemke et al. 1997, Murray et al. 1998). It has also been demonstrated that stratification can result in more pronounced differences between different depths sampled in 1 yr than the inter-annual difference at the same depth (Murray et al. 1998). This suggests genetically stable and persistent bacterioplankton. However, hard evidence of genetic stability in bacterioplankton populations over long time periods will be difficult to provide, but examples from other sources can be found. An interesting case of genetic stability is seen in the rpoB and pla gene sequences of the Yersinia pestis (the cause of plague). Samples from victims of the epidemics 400 yr ago have been obtained and compared to present isolates, and the comparison demonstrates complete identity of the 2 genes (Drancourt et al. 1998).

It has been argued that the gradual divergence that will inevitably occur as the result of minor mutational events and reading errors will require recombination as a stabilizing mechanism (Cohan 1995). If true, this genetic exchange has the potential to constrain intracluster divergence. Transduction is believed to be an important mechanism for transfer of DNA in bacterioplankton, and thereby potentially recombination (Bergh et al. 1989, Fuhrman \& Suttle 1993, Jiang \& Paul 1998). Jiang \& Paul (1998) estimated the frequency of transduction to be between 0 and 100 transductants $\mathrm{l}^{-1} \mathrm{~d}^{-1}$ in an area off the coast of Florida. Although seemingly small, these numbers are significant when considering extended time periods and large areas. These estimates were obtained by a transduction model using a single phage-host system (Jiang \& Paul 1998). In a concurrent study of a large number of phage-host systems isolated in the North Sea, Wichels et al. (1998) demonstrated that multiple phage species can infect the same Pseudoalteromonas species. This would suggest even higher transduction frequencies in complex communities, giving support to the notion of frequent recombination.

When entire genes are transferred the prevailing selection pressure may result in the acquisition of new genetic traits. However, it may be argued that the bacterial chromosome can resist neutral change when no selection pressure is acting. This can be seen in the high degree of conservation in genome size and gene order. Selective constraints operate on the bacterial chromosome in order to maintain a basic organization. Examples of such constraints are the need for the terminus to oppose the origin of replication to minimize chromosomal replication rates (Riley \& Sanderson 1990), and the maintenance of an advantageous orientation of transcription relative to the direction of replication (Brewer 1990). Further constraints have been outlined by Bergthorsson \& Ochman (1997). Thus, to compensate for any negative effects that could be caused by changed genome structure the added benefit of the information provided by the new DNA must be considerable. Extrachromosomal DNA, on the other hand, can be allowed to reside in the cell with less constraints and mediate exchangeable potential features to the cell.

Bacterioplankton require physical transport of water parcels for efficient genetic transfer to occur over large 
sea areas. Eilola (1998) produced a valuable estimate of horizontal transfer of water, using spreading of juvenile fresh water as a tracer. When comparing these results obtained in the Baltic Sea to tracer experiments in other sea areas, Eilola arrived at an average spreading velocity of $5 \mathrm{~cm} \mathrm{~s}^{-1}$. This means that within months surface waters will spread and mix over large sea areas (Eilola 1998). A second important route for the transfer of bacterial DNA is sea spray (Blanchard \& Syzdek 1970, Baylor et al. 1977). Bacteria, as well as potentially transducing phages, could be transported at windspeeds typically ranging from 5 to $20 \mathrm{~m} \mathrm{~s}^{-1}$, which means a 100 -fold higher transfer rate than surface water transport.

In the present study, we concluded that although a few species could be found widely distributed in different oceans, more commonly 'worldwide' distributions could be assigned to bacteria at the genus level. This result is in agreement with a low degree of community DNA hybridization between samples from different sea areas (Lee \& Fuhrman 1991), and the records of ubiquitous identical clones (DeLong 1992, Fuhrman et al. 1993, Mullins et al. 1995). An encouraging observation in our study was the high proportion of cultured isolates that demonstrated high similarity to reported environmental clones. This indicates a wealth of diverse indigenous bacteria yet to be explored under culture conditions.

Acknowledgements. Skilful technical assistance was provided by Siv Sääf, Johanna Hemphälä, and Berit LangkildeMoller. We thank Farooq Azam and Fereidoun Rassoulzadegan for kind support during our visits to their laboratories. We also thank Stephen J. Giovannoni and 2 anonymous reviewers for useful comments on the manuscript. This work was supported by the Swedish Natural Science Council (NFR), grant BU 04452-321.

\section{LITERATURE CITED}

Acinas SG, Antón J, Rodríguez-Valera F (1999) Diversity of free-living and attached bacteria in offshore western Mediterranean waters as depicted by analysis of genes encoding 16S rRNA. Appl Environ Microbiol 65:514-522

Amann RI, Lin C, Key R, Montgomery L, Stahl DA (1992) Diversity among Fibrobacter isolates: towards a phylogenetic classification. Syst Appl Microbiol 15:23-31

Amann RI, Ludwig W, Schleifer KH (1995) Phylogenetic identification and in situ detection of individual microbial cells without cultivation. Microbiol Rev 59:143-169

Baylor ER, Baylor MB, Blanchard DC, Syzdek LD, Appel C (1977) Virus transfer from surf to wind. Science 198: $575-580$

Bergh $\varnothing$, Börsheim KY, Bratbak G, Heldal M (1989) High abundance of viruses found in aquatic environments. Nature 340:467-468

Bergthorsson U, Ochman $\mathrm{H}$ (1997) Evolution of the $E$. coli genome. In: de Bruijn FJ, Lupski JR, Weinstock GM (eds) Bacterial genomes: physical structure and analysis. Chapman \& Hall, New York, p 177-186

Blanchard DC, Syzdek L (1970) Mechanism for the water-toair transfer and concentration of bacteria. Science 170 . $626-628$

Bowman JP, McCammon SA, Brown MV, Nichols DS, McMeekin TA (1997) Diversity and association of psychrophilic bacteria in Antarctic sea ice. Appl Environ Microbiol 93:3068-3078

Brewer (1990). Replication and the transcriptional organisation of the Escherichia coli chromosome. In: Drlica K, Riley $M$ (eds) The bacterial genome. American Society for Microbiology, Washington, DC, p 61-83

Chandler DP, Li SM, Spadoni M, Drake GR, Balkwill DL, Fredrickson JK, Brockman FJ (1997) A molecular comparison of culturable aerobic heterotrophic bacteria and $16 \mathrm{~S}$ rDNA clones derived from a deep subsurface sediment. FEMS Microbiol Ecol 23:131-144

Cohan FM (1995) Does recombination constrain neutral divergence among bacterial taxa? Evolution 49:164-175

DeLong EF (1992) Archaea in coastal marine environments. Proc Natl Acad Sci USA 89:5685-5689

DeLong EF, Franks DG, Alldredge AL (1993) Phylogenetic diversity of aggregate-attached vs. free-living marine bacterial assemblages. Limnol Oceanogr 38:924-934

Devereux R, He SH, Doyle CL, Orkland S, Stahl DA, LeGall J, Whitman WB (1990) Diversity and origin of Desulfovibrio species: phylogenetic definition of a family. J Bacteriol 172:3609-3619

Dobson SJ, McMeekin TA, Franzmann PD (1993) Phylogenetic relationships between some members of the genera Deleya, Halomonas and Halovibrio. Int J Syst Bacteriol 43: 665-673

Drancourt M, Aboudharam G, Signoli M, Dutour O, Raoult D (1998) Detection of 400-year-old Yersinia pestis DNA in human dental pulp: an approach to the diagnosis of ancient septicemia. Proc Natl Acad Sci USA 95: $12637-12640$

Eilola K (1998) Oceanographic studies of the dynamics of fresh water, oxygen and nutrients in the Baltic Sea. Thesis, Publ A30 1998, Gothenburg University

Faude UC, Höfle MG (1997) Development and application of monoclonal antibodies for in situ detection of indigenous bacterial strains in aquatic environments. Appl Environ Microbiol 63:4534-4542

Field KG, Gordon D, Wright T, Rappé M, Urbach E, Vergin K, Giovannoni SJ (1997) Diversity and depth-specific distribution of SAR11 cluster rRNA genes from marine planktoric bacteria. Appl Environ Microbiol 63:63-70

Fuhrman JA, Campbell L (1998) Microbial microdiversity. Nature 393:410-411

Fuhrman JA, Suttle CA (1993) Viruses in marine planktonic systems. Oceanography 6:51-63

Fuhrman JA, McCallum K, Davis AA (1992) Novel major archaebacterial group from marine plankton. Nature 356 : $148-149$

Fuhrman JA, McCallum K, Davis AA (1993) Phylogenetic diversity of subsurface marine microbial communities from the Atlantic and Pacific oceans. Appl Environ Microbiol 59:1294-1302

Fuhrman JA, Lee SH, Masuchi Y, Davis AA, Wilcox RM (1994) Characterization of marine procaryotic communities via DNA and RNA. Microb Ecol 28:133-145

Giovannoni SJ (1991). The polymerase chain reaction. In: Stackebrandt E, Goodfellow $M$ (eds) Sequencing and hybridization techniques in bacterial systematics. John 
Wiley \& Sons, Inc, New York, p 177-201

Giovannoni SJ, Britschgi TB, Moyer CL, Field KJ (1990) Genetic diversity in Sargasso Sea bacterioplankton. Nature 345:60-63

González JM, Moran MA (1997) Numerical dominance of a group of marine bacteria in the alpha-subclass of the class Proteobacteria in coastal seawater. Appl Environ Microbiol 63:4237-4242

Großkopf $R$, Janssen PH, Liesack W (1998) Diversity and structure of the methanogenic community in anoxic rice paddy soil microcosms as examined by cultivation and direct $16 \mathrm{~S}$ rRNA gene sequence retrieval. Appl Environ Microbiol 64:960-969

Höfle M. Brettar I (1995) Taxonomic diversity and metabolic activity of microbial communities in the water column of the central Baltic Sea. Limnol Oceanogr 40:868-874

Höfle MG, Brettar I (1996) Genotyping of heterotrophic bacteria from the central Baltic Sea by use of low-molecularweight RNA profiles Apni Fnviron Microbiol 62: $1383-1390$

Jannasch HW, Jones GE (1959) Bacterial populations in sea water as determined by different methods of enumeration. Limnol Oceanogr 4:128-139

Jiang SC, Paul JH (1998) Gene transfer by transduction in the marine environment. Appl Environ Microbiol 64: $2780-2787$

Kälmbach S, Manz W, Szewzyk U (1997) Isolation of new bacterial species from drinking water biofilms and proof of their in situ dominance with highly specific $16 \mathrm{~S}$ rRNA probes. Appl Environ Microbiol 63:4164-4170

Kogure K, Simidu U, Taga N (1979) A tentative direct microscopic method for counting living marine bacteria. Can J Microbiol 25:415-420

Lane DL, Pace B, Olsen GJ, Stahl DA, Sorgin ML, Pace NR (1985) Rapid determination of 16S rRNA sequences for phylogenetic analysis. Proc Natl Acad Sci USA 82: 6955-6959

Lee S, Fuhrman JA (1991) Spatial and temporal variation of natural bacterioplankton assemblages studied by total genomic DNA cross-hybridization. Limnol Oceanogr 36: $1277-1287$

Malik KA, Schlegel HG (1981) Chemolithoautotrophic growth of bacteria able to grow under $\mathrm{N}_{2}$-fixing conditions. FEMS Microbiol Lett 11:63-67

Moran MA, Rutherford LT, Hodson RE (1995) Evidence for indigenous Streptomyces populations in a marine environment determined with a 16S rRNA probe. Appl Environ Microbiol 61:3695-3700

Mullins TD, Britschgi TB, Krest RL, Giovannoni SJ (1995) Genetic comparisons reveal the same unknown bacterial lineages in Atlantic and Pacific bacterioplankton communities. Limnol Oceanogr 40:148-158

Murray AE, Preston CM, Massana R, Taylor LI, Blakis A, Wu $K$, DeLong EF (1998) Seasonal and spatial variability of bacterial and archaeal assemblages in the coastal waters near Anvers Island, Antarctica. Appl Environ Microbiol 64:2585-2595

Murray RGE, Brenner DJ, Colwell RR, De Vos P, Goodfellow $M$, Grimont PAD, Pfenning N, Stackebrandt E, Zavarzin GA (1990) Report of the ad hoc committee on approaches

Editorial responsibility: Tom Fenchel,

Helsinger, Denmark to taxonomy within the protobacteria. Int J Syst Bacteriol $40: 213-215$

Nyström T (1998) To be or not to be: the ultimate decision of the growth-arrested bacterial cell. FEMS Microbiol Rev 21:283-290

Pace NR (1996) New perspectives on the natural microbial world: molecular microbial ecology. ASM News 62 $463-470$

Pinhassi J, Hagström $\AA$ (2000) Seasonal succession in marine bacterioplankton. Aquat Microb Ecol 21:245-256

Pinhassi J, Zweifel UL, Hagström $\AA$ (1997) Dominant marine bacterioplankton species found among colony-forming bacteria. Appl Environ Microbiol 63:3359-3366

Pinhassi J, Azam F, Hemphälä J, Long RA, Martinez J, Zweifel UL, Hagström $\AA$ (1999) Coupling between bacterioplankton species composition, population dynamics and organic matter degradation. Aquat Microb Ecol 17 $13-26$

Rehnstam AS, Bäckman S, Smith DC, Azam F, Hagström \& (1993) Blooms of sequence-specific culturable bacteria in the sea. FEMS Microbiol Ecol 102:161-166

Riley $M$, Sanderson KE (1990) Comparative genetics of Escherichia coli and Salmonella typhimurium. In: Drlica K Riley M (eds) The bacterial genome. American Society for Microbiology, Washington, DC, p 85-95

Stackebrandt E, Goebel BM (1994) Taxonomic note: a place for DNA-DNA reassociation and 16S rRNA sequence analysis in the present species definition in bacteriology Int J Syst Bacteriol 44:846-849

Suzuki MT, Rappé MS, Haimberger ZW, Winfield H, Adair N, Ströbel J, Giovannoni SJ (1997) Bacterial diversity among small-subunit rRNA gene clones and cellular isolates from the same seawater sample. Appl Environ Microbiol 63 983-989

Tuomi P, Torsvik T, Heldal M, Bratbak G (1997) Bacterial population dynamics in a meromictic lake. Appl Environ Microbiol 63:2181-2188

Wayne LG, Brenner DJ, Colwell RR, Grimont PAD, Kandler O, Krichevsky MI, Moore LH, Moore WEC, Murray RGE, Stackebrandt E, Starr MP, Trüper HG (1987) Report of the ad hoc committee on reconciliation of approaches to bacterial systematics. Int J Syst Bacteriol 37:463-464

Weinbauer MG, Höfle MG (1998) Distribution and life strategies of two bacterial populations in a eutrophic lake. Appl Environ Microbiol 64:3776-3783

Wichels A, Biel SS, Gelderblom HR, Brinkhoff T, Muyzer G Schütt C (1998) Bacteriophage diversity in the North Sea Appl Environ Microbiol 64:4128-4133

Wiik R, Stackebrandt $E$, Valle O, Daae FL, Rødseth OM Andersen K (1995) Classification of fish-pathogenic Vibrios based on comparative 16S rRNA analysis. Int J Syst Bacteriol 45:421-428

Yoon JH, Lee ST, Park YH (1998) Inter-and intraspecific phylogenetic analysis of the genus Nocardioides and related taxa based on $16 \mathrm{~S}$ rDNA sequences. Int J Syst Bacteriol 48 $187-194$

Ziemke F, Brettar I, Höfle MG (1997) Stability and diversity of the genetic structure of a Shewanella putrefaciens population in the water column of the central Baltic. Aquat Microb Ecol 13:63-74

Submitted: September 7, 1999; Accepted: February 29, 2000 Proofs received from author(s): May 25, 2000 